\title{
Assessment of Agricultural Extension Students' Interest in Providing Private Extension Services in Nigeria
}

\author{
S.A. Adesoji ${ }^{1 *}$, M. Famakinwa ${ }^{1}$ and A.E. Eghosa ${ }^{1}$ \\ Received: $25^{\text {th }}$ April $2018 /$ Accepted $4^{\text {th }}$ October 2018
}

\begin{abstract}
Purpose: Agricultural extension graduates do not get jobs and farmers are not getting agricultural extension services, and therefore, both the farmers and agricultural graduates do not receive benefits. The study assessed the interest of agricultural extension students in providing private extension services to farmers, examined their perception towards private extension services and identified extension skills possessed by the students.
\end{abstract}

Research Method: The study comprised all the final year students in the Universities in Osun State. A two - stage sampling procedure was used to select the respondents. One university was selected from each category of federal, state and private. A total of 68 respondents were selected and interviewed. Data collected were analyzed with descriptive and inferential statistics.

Findings: The results show that the mean age, mean years of formal education of the respondents were $23.75 \pm 2.02$ and $17.40 \pm 1.16$, respectively. About half (51.5\%) of the respondents had positive perception towards the private extension service while 57 percent had high interest in providing private extension services. Majority of them possessed teaching skills (97.1\%), innovation dissemination skills (95.5\%) and communication skills (88.2\%). Also, sources of agricultural information available $(\chi 2=22.448)$, types of sponsors $(\chi 2=6.102)$ and marital status $(\chi 2=16.535)$ had a significant association with respondents' interest in providing private agricultural extension services.

Research Limitation: The study focuses on the interest of agricultural extension graduates to provide private extension services; however, these graduates may have an interest in other areas that have not been investigated.

Original Value: The study provides an insight to show the interest and capability of agricultural students to be engaged in private extension services as a livelihood.

Keywords: Assessment, extension, interest, private, student

\section{INTRODUCTION}

Agriculture remains as the bedrock of Nigerian economy, employing about $70 \%$ of the population and contributing about $43 \%$ of the GDP (Central bank of Nigeria, 2015). A crucial sub-sector of agriculture is the agricultural extension service. Extension serves as the conduit, linking stakeholders in agriculture thereby, facilitating agricultural and rural development and all its attendant benefits such as food security, poverty elimination and enhanced livelihood. The relevance of agricultural extension guaranteed its existence in the colonial and post-colonial Nigeria. However, agriculture development and practice in Nigeria is faced with many challenges such as pest and diseases, climatic change, environmental

\footnotetext{
${ }^{1 *}$ Department of Agricultural Extension and Rural Development, Obafemi Awolowo University, Ile-Ife, Osun State, Nigeria. dapadesoji@yahoo.co.uk ORCID http://orcid.org/0000-0001-5286-7966
} 
hazards, poor storage and processing facilities, poor rural development, etc among them.

With the need to overcome these challenges and also to improve agricultural practices, researchers are daily probing into the causes of these problems with the aim of proffering solutions to them with the aim of developing better farming practices to the ultimate aim of sustainable growth and development in the agricultural sector. Research findings need to be applied on the field by the farmers for better production and yield; consequently, there is a need to link the farmers who encounter the challenges together for extension personnel to provide solutions to the challenges (Adejo, Okwu and Ibrahim, 2012). Mgbada (2010) defined agricultural extension as an informal educational system which assists rural dwellers in improving farming methods and techniques and other agro-based occupation, increasing production and service efficiency, income and improving the socio-economic and educational levels of the rural dwellers. Essentially, agricultural extension provides farmers with the scientific knowledge in order to solve their problems.

However, the present extension system in Nigeria, characterized by public extension service executed by Ministries of Agriculture and Agricultural Development Programmes (ADPs) is faced with several problems which include the lack of a legislated agricultural extension policy, frequent change in policy; grossly inadequate and untimely funding; poorly motivated extension staff; high level of engagement of extension staff in non-extension duties; low private sector participation; weak Research-Extension-Farmer-Inputs Linkage System (REFILS); driven by ineffective topdown, supply-driven extension approaches; and a general absence of accountability in the public sector (Adejo et al., 2012). Apart from the above constraints that render public extension service delivery ineffective, Nigerian farmers have poor access to extension services due to poor public relation of extension workers with the rural dwellers, illiteracy among farmers, poor radio and television signals in rural areas, insufficient fund to purchase newsletters, leaflets, community newspapers and bad feeder roads which make farm visits by extension workers difficult (Arokoyo, 2005). In the view of Benor and Baxter (1984) which posited that no sustained high level of agricultural production and income are possible without an effective agricultural extension services supported by agricultural research, that is relevant to farmers' need.

In a bid to overcome these problems facing public agricultural extension service, there has been a strong call for the participation of the private sector in the provision of agricultural extension services which has led to the involvement of many non-governmental organizations (NGOs) (Ajayi, 2006). There are two kinds of NGOs however, NGOs whose motive is non-profit and those whose motive is profit making. According to Yahaya and Luka (2012) this situation encouraged good spirited individuals and organizations to come together to form non-governmental organizations/ private commercial extension agents in an attempt to change the lifestyle of the rural dwellers for better. According to Farinde and Adisa (2005), majority of the NGOs were founded primarily for agricultural and technology dissemination with other activities related to credit, training, social service and culture.

Over the years, studies have identified ways through which NGOs have been of assistance to the government and the entire population of the country in the area of agriculture and rural development (Yahaya and Luka, 2012). The works of Ajayi (2006), Farinde and Atteh (2009), and Adamu (2014) further strengthened the call by assessing farmers' willingness to pay for agricultural extension services and these works have yielded positive results as many of the farmers were willing to pay for an effective extension service delivery. With an increasing calls for the participation of the private sector in provision of agricultural extension services as one of the options for effective agricultural transformation in Nigeria, given that the public 
sector has not faired too well in extension service delivery ever since the withdrawal of the sponsorship of agricultural development programmes by the world bank. There is a need to assess the interest of intending undergraduate students of Agricultural Extension in providing private extension service to farmers after their graduation, hence this study.

\section{Objective of the study}

The main objective of this study is to assess the interest of agricultural extension students in providing private extension services in Osun State, Nigeria.

Specific objectives included to

i. describe the demographic characteristics of the respondents;

ii. exarmine the respondents' perception towards private extension service delivery;

iii.determine the interest of respondents to provide private agricultural extension services;

iv. identify extension skills possessed by the respondents; and

v. determine association between the demographic characteristics of the respondents and their interest in providing private extension service.

\section{MATERIALS AND METHODS}

The study was carried out in Osun State between January and August 2017. Osun State has one federal, one state and six private universities. The population of the study comprised of all 500 level undergraduate students of the Department of Agricultural Extension in selected universities within the study area. A two-stage sampling procedure was used to select the respondents for the study. At the first stage, one university was purposively selected from each of the three categories of universities. These are Bowen University, Osun State University (UNIOSUN) and Obafemi Awolowo University (OAU) which were selected from private, state, and federal universities, respectively that offered Agricultural Extension and Rural Development. At the second stage, all final year students of the Department of Agricultural Extension and Rural Development were purposively selected in all three selected institutions for an interview. There were 32 students from OAU, 24 students from UNIOSUN and 12 students from Bowen University, making a total of sixty eight students in all. This category of students were chosen because they were about to face their professional career choice. A validated and pre-tested questionnaire was used to elicit information on demographic characteristics, their perception towards private extension service, their interest and the extension skills possessed by the respondents. Primary data collected were analysed using both descriptive and inferential statistics such as frequency counts, percentages, means, standard deviation and Chi-square analysis.

The dependent variable for this study is conceptualized as interest of students in providing private extension service. The respondents were as to indicate their interest through response to eight declarative statements which were rated on a five point Likert scale and were scored 5 points for Strongly Agree (SA), 4 points for Agree (A), 3 points for Neutral (N), 2 points for Disagree (D) and 1 point for Strongly Disagree Agree (SD) as used by Ayanda, et al., (2012), Yeboah, Kumi, and Awuah, (2013) and Sultan (2017) and which was modified to suit the research purpose. The total interest score per respondent was further classified into two using mean as low and high level of interest in providing private extension service.

\section{RESULTS AND DISCUSSION}

Socio economic characteristics of respondents

Results in Table 01 show that majority (64.7\%) of the respondents fell within the age group of 23 and 25 years with the mean age of $23.8 \pm 2.0$ 
years. This implies that they are young and this age is typical for undergraduates in Nigerian tertiary institutions; indicating that respondents were in their active age, and this is an advantage to the practice of agricultural extension as they have high energy and physical strength to practice, and also they are more open minded and willing to try out new things. More than half $(52.9 \%)$ of the respondents were female while 47.1 percent were male. This implies that although both males and females were involved in the course of study, more females were involved in Agricultural Extension than males. This observation might be due to the fact that Agricultural Extension is more of social science (applied behavioural science) than natural science. This result is similar to the findings of Ojebiyi et al., (2015) which established that almost equal numbers of male and female undergraduate students in Federal University of Agriculture, Abeokuta (FUNAAB) Ogun State were studying Agriculture. The majority of students (97.1\%) were single while 2.9 percent of the respondents were married. This result implies that majority of the respondents were not saddled with a lot of responsibilities associated with marriage and raising a family. Hence, they have more time to effectively provide private agricultural extension services to rural dwellers. Majorities (95.6\% and $77.9 \%)$ were proficient in English language and Yoruba language, respectively. This implies that the majority of students were able to speak both Yoruba and English fluently which has a direct significance on the effective communication of agricultural extension messages to the rural dwellers because majority of people in the study areas understand and speak Yoruba only. Majority (95.6\%) indicated that their parents and relatives were their sponsors while 4.4 percent indicated self-sponsor. This implies that majority of the respondents were still under the control of their parents which could influence their decision to provide private extension service after graduation. Further results in Table 1 show that the respondents sourced agricultural information mostly from their lecturers
$(88.2 \%)$, closely followed by newspaper/ journals/magazines $(77.9 \%)$, social media platform $(76.5 \%)$, seminars and talks $(76.5 \%)$, radio and television (73.\%5), colleagues and friends $(55.9 \%)$ as well as family members $(33.8 \%)$. It could be inferred that because the respondents are educated, they utilized various sources of agricultural information which could be an added advantage and influence their competence and effectiveness in disseminating useful innovations and improved technologies to the farmers by the time they take up the job of private extension service.

\section{Perception towards private extension services delivery}

The results in Table 02 show that the perceptional statements that ranked higher than the grand mean score of 3.16 include the statements that private extension services in Nigeria would help reduce unemployment (mean=3.54), privatization will improve linkages between research and extension (mean $=3.50)$, privatization will improve employment opportunities for extension graduates (mean $=3.49$ ), programmes in private extension are educational and beneficial to farmers (mean=3.40), privatization will make extension services to be directed at specific need of people (mean $=3.32$ ), private extension services would serve farmers better than public extension (mean=3.26), monitoring and evaluation of extension programmes are easier under private extension than public extension service (mean $=3.22)$, Private extension service in Nigeria is a viable business (mean=3.21) and privatization will make it possible for more farmers to be reached (mean=3.21). The implication of this finding was that respondents strongly agreed that these opinions were the major determinants of the respondents in showing interest to provide private extension service delivery while other perceptional statements were not significant to them in providing private extension delivery. 
S.A. Adesoji, M. Famakinwa and A.E. Eghosa

Table 01: Distribution of respondents by selected socio- economic characteristics $(n=68)$

\begin{tabular}{|c|c|c|c|c|}
\hline Personal Characteristics & Frequency & Percentage & Mean & Std Deviation \\
\hline \multicolumn{5}{|l|}{ Age } \\
\hline$\leq 22 \mathrm{yrs}$ & 14 & 20.6 & & \\
\hline $23-25 y r s$ & 44 & 64.7 & 23.8 & 2.0 \\
\hline$\geq 26 \mathrm{yrs}$ & 10 & 14.7 & & \\
\hline \multicolumn{5}{|l|}{ Sex } \\
\hline Male & 32 & 47.1 & & \\
\hline Female & 36 & 52.9 & & \\
\hline \multicolumn{5}{|l|}{ Marital status } \\
\hline Single & 66 & 97.1 & & \\
\hline Married & 2 & 2.9 & & \\
\hline \multicolumn{5}{|l|}{ Sources of Agric. information ${ }^{* *}$} \\
\hline Lecturers & 60 & 88.2 & & \\
\hline Newspaper/journal/magazine & 53 & 77.9 & & \\
\hline Social media platform & 52 & 76.5 & & \\
\hline Seminars \& talks & 52 & 76.5 & & \\
\hline Radio \& television & 50 & 73.3 & & \\
\hline Colleagues \& friends & 38 & 55.9 & & \\
\hline Family members & 23 & 33.8 & & \\
\hline \multicolumn{5}{|l|}{ Sponsors } \\
\hline Parents \& relatives & 65 & 95.6 & & \\
\hline Self & 3 & 4.4 & & \\
\hline Community & 0 & 0 & & \\
\hline Others & 0 & 0 & & \\
\hline \multicolumn{5}{|l|}{ Language proficiency** } \\
\hline English & 65 & 95.6 & & \\
\hline Yoruba & 53 & 77.9 & & \\
\hline Igbo & 0 & 0 & & \\
\hline Others & 3 & 4.4 & & \\
\hline
\end{tabular}

** multiple response

Source: Field survey, 2017

Perceptional index score with the mean score of 49.6 was employed to categorise respondents into positive (mean score and above) and negative (below mean score) perceptions to provide extension service. Results in Table 03 reveals that $48.5 \%$ of the respondents had negative perception towards private extension service delivery while more than half $(51.5 \%)$ had positive perception towards private extension service delivery. The fact that almost half of the respondents exhibited positive perception towards private extension service delivery would influence their interest in providing private extension service to farmers, eventually reduce unemployment among graduates of agricultural extension and enhance increase extension delivery to farmers. This implies that there is potential for private extension service in Nigeria if government at various levels could provide enabling environment for it to thrive through formulation of good agricultural extension policies that will favour private extension service. 
Table 02: $\quad$ Respondents' perceptional scores towards private extension services delivery $(\mathrm{n}=68)$

\begin{tabular}{lcc}
\hline \multicolumn{1}{c}{ Variables } & Mean & Ranked \\
\hline Total privatization of extension services in Nigeria is possible & 2.60 & $15^{\text {th }}$ \\
Private extension service in Nigeria is a viable business & 3.21 & $8^{\text {th }}$ \\
Private extension services in Nigeria would help to reduce unemployment & 3.54 & $1^{\text {st }}$ \\
Private extension services would serve farmers better than public extension & 3.26 & $5^{\text {th }}$ \\
Only extension graduates should be involved in private extension service & 2.90 & $12^{\text {th }}$ \\
Private extension offers equal opportunity for small holders and large scale farmers & 2.96 & $11^{\text {th }}$ \\
Monitoring and evaluation of extension programmes are easier under private & 3.22 & $7^{\text {th }}$ \\
extension than public extension service & & \\
Private extension would set out to cheat farmers as standardization of payment are & 2.79 & $13^{\text {th }}$ \\
not available & 3.40 & $4^{\text {th }}$ \\
Programmes in private extension are educational and beneficial to farmers & 3.13 & $10^{\text {th }}$ \\
Private extension is not just profit oriented but serve as aid to farmers & 3.49 & $3^{\text {rd }}$ \\
Privatization will improve employment opportunities for extension graduates & 2.66 & $14^{\text {th }}$ \\
Privatization will make extension services unaffordable to farmers & 2.43 & $16^{\text {th }}$ \\
Privatization will encourage income inequality & 3.21 & $8^{\text {th }}$ \\
Privatization will make it possible for more farmers to be reached & 3.50 & $2^{\text {nd }}$ \\
Privatization will improve linkages between research and extension & 3.32 & $5^{\text {th }}$ \\
\hline Privatization will make extension services to be directed at specific need of people & & \\
\hline
\end{tabular}

Grand mean $=3.16$

Source: Computed from field survey, 2017

Table 03: Level of perception towards private extension service delivery $(n=68)$

\begin{tabular}{lccc}
\hline \multicolumn{1}{c}{ Level } & Perceptional score & Frequency & Percentage \\
\hline Negative & Below 49.6 & 33 & 48.5 \\
Positive & 49.6 and above & 35 & 51.5 \\
\hline
\end{tabular}

Source: Computed from field survey, 2017

\section{Interest in providing private extension service}

Results in Table 04 shows the ranked mean scores respondents' interest in providing private extension service delivery. The statements that ranked higher than the grand mean score of 2.70 include the statements that "I have a strong desire to start my own private extension services" (mean=3.37), "I am prepared to do anything to provide private extension service after my graduation" (mean=3.32), "I have the requisite technical knowledge to be a successful private agricultural extension personnel" (mean=3.25), "If there is enabling environment for me to provide private extension service I will certainly do" (mean $=3.20$ ) and "I am interested in providing knowledge oriented private extension services" (mean=2.76). The implication of this finding was that respondents in the study had strong intention and interest to provide private extension service to farmers after graduation if enabling environment could be provided. This means there is hope for farmers and agricultural extension service in Nigeria even if the government stop recruiting new agricultural extension staff into its public service.

\section{Level of respondents' interest in the provision of private agricultural extension services}

Results in Table 05 show that 42.6 percent of the respondents had a low interest level while higher proportion $(57.4 \%)$ of the respondents had a high interest level in providing private agricultural extension services to the farmers 
after graduation. This implies that majority of the respondents were interested in providing private extension services after their graduation from the university. Because higher proportions of the students are interested in private extension services, it means that agricultural extension system will be enhanced in Nigeria. More farmers will be visited and hope of increasing agricultural production is higher. This finding however, is not surprising because, while the number of university graduates joining the labour market increases each year in Nigeria, there are not enough jobs in both public and private sectors to absorb all youths seeking employment. Many of these university agricultural graduates could be engaged in private agricultural extension services as means of survival.

\section{Perceived possession of extension skills by the respondents}

The respondents were asked to indicate extension skills they had and exhibited at one time or the other during the course of their training especially during their practical year. The results in Table 06 show that respondents mostly indicated that they possessed teaching skills (97.1\%), followed by innovation dissemination skills (95.5\%), communication skills $(88.2 \%)$, advisory service skills $(77.9 \%)$ respectively. These are the skills required for a good extension services delivery. The teaching skills to be able to educate the farmers, the innovation skills to be able to introduce new technologies to the farmers, advisory skills to be able to offer sustainable advice to farmers and the communication skills would assist the respondents to reach the farmers using various communication methods. If the skills are well developed and utilized, the respondents would operate very good private extension services. The students perceived that they had the requisite skills needed to provide private agricultural extension services which would enable them to effectively discharge extension service delivery to the farmers when they start their own extension services.

Table 04: Distribution of respondents by interest in providing private extension service

\begin{tabular}{lcc}
\hline \multicolumn{1}{c}{ Variables } & Mean & Ranked \\
\hline I have a strong desire to start my own private extension services & 3.37 & $1^{\text {st }}$ \\
I am interested in seeking the latest agricultural innovations from research institutes & 1.99 & $7^{\text {th }}$ \\
I am prepared to do anything to provide private extension service after my graduation & 3.32 & $2^{\text {nd }}$ \\
I am interested in providing knowledge oriented private extension services & 2.76 & $5^{\text {th }}$ \\
I have the requisite technical knowledge to be a successful private agricultural extension personnel & 3.25 & $3^{\text {nd }}$ \\
If there is enabling environment for me to provide private extension service I will certainly do. & 3.20 & $4^{\text {th }}$ \\
I have strong interest in seeking the latest agricultural innovations from subject-matter- & 2.07 & $6^{\text {th }}$ \\
specialists & 1.96 & $8^{\text {th }}$ \\
I would love to provide demand-driven private extension demand &
\end{tabular}

Grand mean $=2.74$

Source: Computed from field survey, 2017

Table 05: Distribution of respondents based on level of interest in the provision of private extension service $(n=68)$

\begin{tabular}{lcccc}
\hline Level & Interest score & Frequency & $\%$ & Mean \\
\hline Low & Below 54.30 & 30 & 42.6 & \\
High & 54.30 and above & 39 & 57.4 & 54.30 \\
\hline
\end{tabular}

Source: Computed from field survey, 2017 
Table 06: Respondents' perceived possession of extension skills $(n=68)$

\begin{tabular}{lcc}
\hline \multicolumn{1}{c}{ Variables } & Frequency & Percentage \\
\hline Innovation dissemination skills & 65 & 95.5 \\
Advisory services ability & 53 & 77.9 \\
Programme planning ability & 44 & 64.7 \\
Programme evaluation skills & 50 & 73.3 \\
Administration and supervision skills & 52 & 76.5 \\
Communication skills & 60 & 88.2 \\
Teaching skills & 66 & 97.0 \\
\hline
\end{tabular}

Source: Field survey, 2017

Relationship between socio-economic characteristics and interest in providing private agricultural extension services

The result of Chi-square analysis on some nominal variables in Table 07 show relationship on sex, $\left(\chi^{2}=2.335 ; \mathrm{p}>0.05\right)$, religion $\left(\chi^{2}=1.209\right.$; $\mathrm{p}>0.05)$, ethnicity $\left(\chi^{2}=0.063 ; \mathrm{p}>0.05\right)$, marital status $\left(\chi^{2}=16.002 ; \mathrm{p} \leq 0.01\right)$ private extension services provision among the respondents. This implies that only marital status had significant relationship with private extension services provision among the respondents. This implies that when respondents are married they would be able to provide private extension better than the unmarried respondents. Other variables like sex, religion and ethnicity as revealed by this study showed that none of them has any relationship with providing private extension services. This implies that all sexes could provide private extension. Also the type of religion or location in terms of ethnicity of the respondents does not influence provision of private extension services.

Results in Table 7 also show the results of correlation analysis of some variables measured in interval and ration scales. The results show that age had no significant relationship with the provision of private extension services among the respondents $(\mathrm{r}=-0.144 ; \mathrm{p}>0.05)$. This implies that respondents at any age (old or young) can provide private extension services to farmers. The number of years spent in educational institutions by the respondents had a positive and significant relationship with the provision of private extension services among farmers $(\mathrm{r}=0.557 ; \mathrm{p}<0.011)$. This implies that the more the number of years the respondents spent in an educational institution, the more the ability of the respondents to provide private extension services for the farmers.

Table 07: Chi-square and Correlation analyses results showing relationship between selected socio-economic characteristics of respondents and their interest in providing private agricultural extension services $(n=68)$

\begin{tabular}{|c|c|c|}
\hline Variables & $\chi^{2}$ value & p-value \\
\hline Sex & 2.335 & 0.311 \\
\hline Religion & 1.209 & 0.546 \\
\hline Ethnicity & 0.063 & 0.969 \\
\hline Marital status & 16.535 & $0.000^{*}$ \\
\hline Correlation & r- value & p-value \\
\hline Age & -0.144 & 0.243 \\
\hline Household size & -0.334 & $0.005 * *$ \\
\hline Monthly income & -0.446 & $0.000 * *$ \\
\hline Number of years spent in education Institutions & 0.557 & $0.001 * *$ \\
\hline
\end{tabular}


Monthly income of the students also had a negative but significant relationship with the provision of private extension services for the farmers $(r=-0.446 ; p<0.05)$. This implies that the smaller the income of the respondents the more their interest to provide private extension services for farmers. This is to say that those respondents that were not getting enough money either from their parents or from other sources had more interest in providing private extension services for the farmers. Also household size is negatively significant with the provision of private extension services by the respondents $(r$ $=-0.334 ; \mathrm{p}<.05)$. This implies that respondents with smaller number of people in their household will likely show more interest to provide private extension services for the farmers.

\section{CONCLUSIONS}

Based on the findings of the study, it is concluded that respondents' source of agricultural information from various sources ranging from their lecturers to family members. They also show positive perception and high interest in providing private extension services to farmers. Their interest in providing private extension services was borne out of the fact that they possess the necessary skills such as teaching, innovation dissemination, advisory and communication skills that are required to effectively provide private extension services to the farmers. Some of the important variables to consider when planning effective private extension services for the farmers are; the number of years spent in schools, monthly income, household size of interested people among others. It is therefore, recommended that government should provide enabling environment by giving institutional support services to agricultural extension graduates who wish to establish private extension services. Also, agricultural extension policy should favour professionalism of agricultural extension services as this would enhance private extension services delivery.

\section{REFERENCE}

Adamu, C. O. (2014). Extension users' view on alternative sources of fund for extension services in Ogun state, Journal of Biology, Agriculture and Healthcare Vol.4, No.12, available online at www.iiste.org DOI: http://dx.doi.org/10.4314/bja.v3i2.41913

Adejo, P E., Okwu, O. J. and Ibrahim, M. K. (2012). Challenges and prospects of privatization of agricultural extension service delivery in Nigeria. Journal of Agricultural Extension and Rural Development Vol. 4(3): 63 - 68. DOI: http://dx.doi.org/10.5772/29022

Ajayi, A. O. (2006). An assessment of farmers' willingness to pay for extension services using the contingent valuation method (CVM): The Case of Oyo State, Nigeria. The Journal of Agricultural Education and Extension. Vol. 12 (2):97-108. DOI: http://dx.doi. org/10.1080/13892240600861567

Alabi, R. A, and Mafimisebi T.E (2004). Increasing Private Participation in Agriculture through Privatization. Paper prepared for presentation at the Farm Management Association of Nigeria Conference, Abuja, Nigeria Oct. 19-21, 1- 7. DOI: http://dx.doi.org/10.17140/uaoj$1-106$

Arokoyo, T. (2005). ICTs Application in Agricultural Extension Service Delivery. In: Adedoyin, F. S. (ed). Agricultural Extension in Nigeria. AESON, Ilorin, 246. DOI: http://dx.doi. org/10.4314/mjar.v7i1.31846 
Ayanda, I. F, Olooto, F., Motunrayo, A., Abolaji, G. T., Yusuf, O. J., Subair, S. K. (2012). Perception of Kwara state university agricultural students on farming as means of future livelihood, International Journal of Agriscience Vol. 2(11): 1053-1061. DOI: http://dx.doi. org/10.4314/jae.v21i3.2

Benor, O. and Baxter, M. (1984). Training and visit extension. Washington DC: The World Bank.3. DOI: http://dx.doi.org/10.1093/wbro/1.2.139

Brownhilder, N. N. (2014). An Assessment of Entrepreneurial Intention among University Students in Cameroon. Mediterranean Journal of Social Sciences. Vol.5(20):542-552. DOI: http:// dx.doi.org/10.5901/mjss.2014.v5n20p542

Central Bank of Nigeria (CBN) (2015). Central Bank of Nigeria Annual report and Statement of Accounts. 2015 available online at www.cenbank.org DOI: http://dx.doi. org/10.1057/9781137493538.0016

Farinde, A. J, Adisa, B.O. (2005). Role of community- based organizations (CBOs), Commodity associations (CAs) and Non-governmental organizations (NGOs) in agricultural extension activities in Nigeria. AESON, ARMTI, Ilorin. pp.208-219. DOI: http://dx.doi.org/10.4314/ gaep.v1i1.34886

Farinde, A. J. and Atteh, A. P. (2009). Tending towards extension privatization in Nigeria: An assessmentof arable crop farmers' willing to pay for extension services in Niger State, Nigeria. Journal of Agriculture and Food Information, Vol.10 (1): 63-75. DOI: http://dx.doi. org/10.1080/10496500802705508

Mgbada, J. U. (2010). Agricultural Extension: The Human Development Prospective, Computer Edge Publishers, Enugu. DOI: http://dx.doi.org/10.4314/gaep.v2i1.34952

National Bureau of Statistics (NBS), (2009). Annual abstract of Statistics, 2009, Federal Government of Nigeria. DOI: http://dx.doi.org/10.1057/aas.2009.19

Ojebiyi, W. G., Ashimolowo, O. R., Odediran, O. F., Soetan, O. S., Aromiwura, O. A. and Adeoye, A. S. (2015). Willingness to Venture into Agriculture-related Enterprises after Graduation among Final Year Agriculture Students of Federal University of Agriculture, Abeokuta. International Journal of Applied Agricultural and Apicultural Research, Vol 11 (1\&2): 103114. DOI: http://dx.doi.org/10.17501/icoaf.2017.3104

Sultan, J. (2017). Entrepreneurial intention among undergraduate agricultural students in Ethiopia:The case of Jimma University. African Journal of Business Management, Vol.11(13): 293-303. DOI: http://dx.doi.org/10.5897/ajbm10.891

Yeboah, A. S., Kumi, E. and Awuah, B. J. (2013). An Assessment of Entrepreneurship Intention among Sunyani Polytechnic marketing student. International Review of Management and Marketing, Vol.3(1), 37-49. DOI: http://dx.doi.org/10.1108/02651330610660056

Yahaha, H. and Luka, E. G. (2012). The Role of Private Extension Agencies in Agricultural Development of Kaduna State, Nigeria: A Case Study of Leventis Foundation Agricultural Training School, Journal of Biology, Agriculture and Healthcare. Vol. 2(10): www.iiste.org ISSN 2224-3208 (Paper) ISSN 2225-093X (Online) DOI: http://dx.doi.org/10.9790/23800351723 